Historical Institutions and Electoral Outcomes The case of India after Decolonization

Shree Saha

Indira Gandhi Institute of Development Research, Mumbai November 2019 


\title{
Historical Institutions and Electoral Outcomes The case of India after Decolonization
}

\author{
Shree Saha \\ Email(corresponding author): shree@igidr.ac.in
}

\begin{abstract}
There is now ample evidence that historical colonial institutions impact contemporary economic outcomes and some suggest that these links might be mediated by the influence of colonial institutions on electoral processes and outcomes. This paper examines this under-researched link in the context of India, focusing on two colonial institutions that potentially influence electoral outcomes - the type of rule, i.e. whether a territory was under direct British rule or whether it was under native rule - and the type of land tenure installed by the British. I measure electoral outcomes by three variables: voter turnout (VT), margin of victory (MV) and electoral competition (EC) and ask: Do historical colonial institutions impact contemporary electoral outcomes and if yes, in what ways? Do such impacts persist in the longer term? I focus specifically on the elections at the cusp of decolonization (1951) and those in 1970 s, to assess short and longer-terms impacts. Results indicate a 4\% higher VT in native ruled areas in the long run and 5\% higher VT in the non-landlord areas in the short run. The latter dissipates in the longer term because of tenancy reforms. I find EC consistently higher in British and landlord areas but no robust impact on $M V$ is noted. These results are consistent with the role played by landlords and erstwhile princes of native states after decolonization. The paper provides evidence on the potentially important mediating role of electoral outcomes in link between historical institutions and economic outcomes and suggests that research on elections should not overlook the role of historical institutions and those exploring the historical origins of economic outcomes should not overlook the role of elections.
\end{abstract}

Keywords: Colonial institution, political institution, democracy, decolonization, path- dependence, elections

JEL Code: B15, B16, B25, B52, D72, P48

\section{Acknowledgements:}

I am indebted to Sudha Narayanan for her guidance in publishing this work. I would also like to thank Aparna Balachandran, Jayati Sarkar, Shubhro Sarkar, Subrata Sarkar, Tirthankar Roy, the participants of the IIT Guwahati, YSI Hanoi and IIM Ahmedabad conferences for their useful comments and suggestions. I am solely responsible for any errors and omissions in this work. 


\title{
Historical Institutions and Electoral Outcomes The case of India after Decolonization
}

\author{
Shree Saha ${ }^{ \pm}$
}

${ }^{ \pm}$Research Associate at Indira Gandhi Institute of Development Research, Mumbai (Email- shree@igidr.ac.in) Address: IGIDR, A.K. Vaidya Marg, Goregaon(East), Mumbai-400065, India.

Acknowledgements: I am indebted to Sudha Narayanan for her guidance in publishing this work. I would also like to thank Aparna Balachandran, Jayati Sarkar, Shubhro Sarkar, Subrata Sarkar, Tirthankar Roy, the participants of the IIT Guwahati, YSI Hanoi and IIM - Ahmedabad conferences for their useful comments and suggestions. I am solely responsible for any errors and omissions in this work. 


\begin{abstract}
There is now ample evidence that historical colonial institutions impact contemporary economic outcomes and some suggest that these links might be mediated by the influence of colonial institutions on electoral processes and outcomes. This paper examines this under-researched link in the context of India, focusing on two colonial institutions that potentially influence electoral outcomes - the type of rule, i.e. whether a territory was under direct British rule or whether it was under native rule - and the type of land tenure installed by the British. I measure electoral outcomes by three variables: voter turnout (VT), margin of victory (MV) and electoral competition (EC) and ask: Do historical colonial institutions impact contemporary electoral outcomes and if yes, in what ways? Do such impacts persist in the longer term? I focus specifically on the elections at the cusp of decolonization (1951) and those in 1970s, to assess short and longer-terms impacts. Results indicate a 4\% higher VT in native ruled areas in the long run and 5\% higher VT in the non-landlord areas in the short run. The latter dissipates in the longer term because of tenancy reforms. I find EC consistently higher in British and landlord areas but no robust impact on $M V$ is noted. These results are consistent with the role played by landlords and erstwhile princes of native states after decolonization. The paper provides evidence on the potentially important mediating role of electoral outcomes in link between historical institutions and economic outcomes and suggests that research on elections should not overlook the role of historical institutions and those exploring the historical origins of economic outcomes should not overlook the role of elections.
\end{abstract}

Keywords: Colonial institution, political institution, democracy, decolonization, pathdependence, elections

JEL Classification: B15, B16, B25, B52, D72, P48 


\section{INTRODUCTION}

Social scientists have long acknowledged the role of institutions in the economic development and growth prospects of countries (Hsiao and Shen 2003; North 1991).The term "institutions" refers to 'humanly devised constraints' (formal or informal) that govern social, political and economic aspects of an individual's life (North 1991). Many institutions that are deemed to influence economic growth and development are themselves often shaped by history. Historical institutions in this sense can have a persisting influence on economic outcomes via a number of channels. Legal and judicial institutions in countries are often legacies of the past (Klerman et al. 2011). Colonized countries tend to inherit political regimes and adopt governance systems of their colonizers; these may vary systematically depending on the identity of the colonizer (Agbor 2015), duration of colonization (Olsson 2009), the era of Independence, the prevalent international political conditions and the initial level of democracy in the country prior to Independence (Lankina 2014). Studies find, for example, that the colonies under direct British rule mostly follow parliamentary system of democracy in comparison to Spanish colonies that follow the presidential system (Persson and Tabellini 2004). Legal and political systems can in turn shape the trajectory of economic growth and development of a country (Klerman et al. 2011). History can also leave an imprint on socio-economic polices such as trade and education, that in turn may lead to better economic conditions. British territories in SubSaharan Africa, for instance, performed better in comparison to French colonies, owing to better education and trade policies followed by the British (Persson and Tabellini 2004; Agbor 2015). Historical institutions also shape social conventions, cultural norms, citizen- 
state relations, trust in government in addition to others, influence economic interaction and outcomes (Ekeh 1983; Becker et al. 2016).

Several studies thus show that historical institutions, including those established by colonizers, have a persistent influence on latter day economic outcomes, even in the long run, a phenomenon referred to as 'institutional overhang' (A. Banerjee and Iyer 2005). While the link between colonial pasts and contemporary economic outcomes, such as economic growth, inequality, agricultural productivity etc. (Hayami and Ruttan 1970; Bertocchi and Canova 2002; Dollar and Kray 2003; Gordon 2010) are well-established, some pathways through which these effects manifest are better researched than others. This paper focuses on one such hypothesized pathway- that electoral outcomes might be a critical mediating factor linking historical colonial institutions and contemporary economic outcomes (A. Banerjee and Iyer 2005). This link between colonial institutions and electoral outcomes has not been examined widely and this paper contributes to better understanding these links (Banerjee and Somanathan 2007)

Uncovering effects of colonial pasts on political and electoral outcomes is however empirically challenging because countries that were colonized might be systematically different from those that were not. Several studies seek to address this by researching countries that had contrasting histories within the same political boundaries. India offers a solution to the empirical challenge of finding an appropriate counterfactual for colonial rule, as at the time of Independence in 1947 it comprised territories that were under direct (colonial) rule as well as those that were part of the princely states where British control was only indirect (native). Studies in the Indian context typically use instrumental variable 
approaches to address the endogeneity of colonial and native rule (described in detail later). The best-known work in this area documents that direct rule areas performed better than indirect rule territories - likely due to differences in electoral outcomes (A.Banerjee and Iyer 2005).

In this work, I focus exclusively on the electoral processes of India, during the years following her independence from the British rule in 1947, when the foundations of democracy were being laid. ${ }^{1}$ Do historical colonial institutions impact latter-day electoral outcomes and if yes, in what ways? Do such impacts persist in the longer term? I assess the outcome of national elections in India, post-decolonization, namely elections of 1951 (short run), 1971 and 1977 (long run) and focus on three specific electoral outcomes- voter turnout, margin of victory and electoral competition in this analysis. The colonial institutions that I evaluate are the twin aspects of direct rule by the British (versus native rule) and the type of land tenure established by the British (Section 2).

The analysis reveals that the native states see a higher voter turnout (4\% higher on an average) only in the longer run. Non-landlord areas have a higher voter turnout in the short run (5\% higher on an average) but such an effect dissipates in the longer run. I find no impact of colonial institutions in the short run for MV. However, in the elections of 1977, the colonial areas have a significantly higher margin of victory (on an average 14.4\% higher). ${ }^{2}$ I find that electoral competition is higher in colonial areas (average of three candidates in short run and five in long run) and landlord dominated areas (average of two

\footnotetext{
${ }^{1}$ It is noted by historians that there exists a lacuna in studies at the phase of decolonization. Historians have carried out extensive research on the periods under colonization and long after decolonization, but not during the period of decolonization (Sarkar 1989; Sarkar 1997; Shani 2017).

2 Owing to the landslide victory of Bharatiya Janata Dal against Indian National Congress, post-Emergency
} 
candidates in 1951 elections which increases to five in elections of 1977), both in the short and long run. At first glance, these results suggest that there might not be consistent and systematic differences caused by differing colonial institutions. Yet, each of these results is explained by distinct differences in class-based politics based on land tenure and the role of princes in native ruled territories, and is discussed later in the paper. Collectively, these suggest that historical colonial institutions do influence latter-day electoral outcomes.

This work is divided into seven major sections. The next section deals with the conceptual pathways, followed by the empirical strategy in the third section. Section 4 discusses the methodology and the data sources used in the analysis. In section 5 and 6, I discuss the results and channels of impact and the last section concludes the study.

\section{Conceptual Pathways}

In this work, I focus on two aspects of British colonial institutions - direct versus indirect rule and the land tenure system. As measures of electoral outcomes, I consider voter turnout, margin of victory and electoral competition (measured by number of candidates contesting elections). These three measures are often used interchangeably, as measures of electoral competition (Vanhanen 2000; 2005). In this analysis, I analyze each of them separately as they signify different aspects of democracy, namely, voter participation, vote distribution and political contestation respectively. 


\section{Direct Versus Indirect Rule}

British rule in India after 1857 was bi-faceted with two kinds of territories - Presidencies and Residencies. Presidencies, also known as the "direct rule" areas, were situated in Bombay, Madras and Calcutta. ${ }^{3}$ In these Presidencies, the Crown had complete control over the administration. On the other hand, Residencies (also known as the "indirect rule areas" or "native") were territories where the Crown, could only oversee through a "resident" or an "agent" e.g. Baroda, Travancore, Rajputana and others (A. Banerjee and Iyer 2005; Wiener 2013). These indirect rule areas were allowed domestic autonomy with preconditions of good governance and were provided with security against foreign invasions. An "agent" or "resident" was located, to represent the Crown in the territory to monitor the day-to-day affairs (Rudolph 1963). On the eve of Independence, India had 562 native states, which were free to join either of the two Dominions, India and Pakistan (Copland 2002). ${ }^{4}$ Figure 1 demonstrates the colonial and native ruled territories based on the recent district boundaries (Census 2011).

\footnotetext{
${ }^{3}$ Administrative powers were bestowed on the Crown through the Government of India Act, 1858.

${ }^{4}$ Even though the native states were "indirect" rule territories, the role of the British agents in the domestic affairs varied significantly across these territories (Qanungo 1967).
} 
Figure 1: Classification of Districts on the Basis of Rule

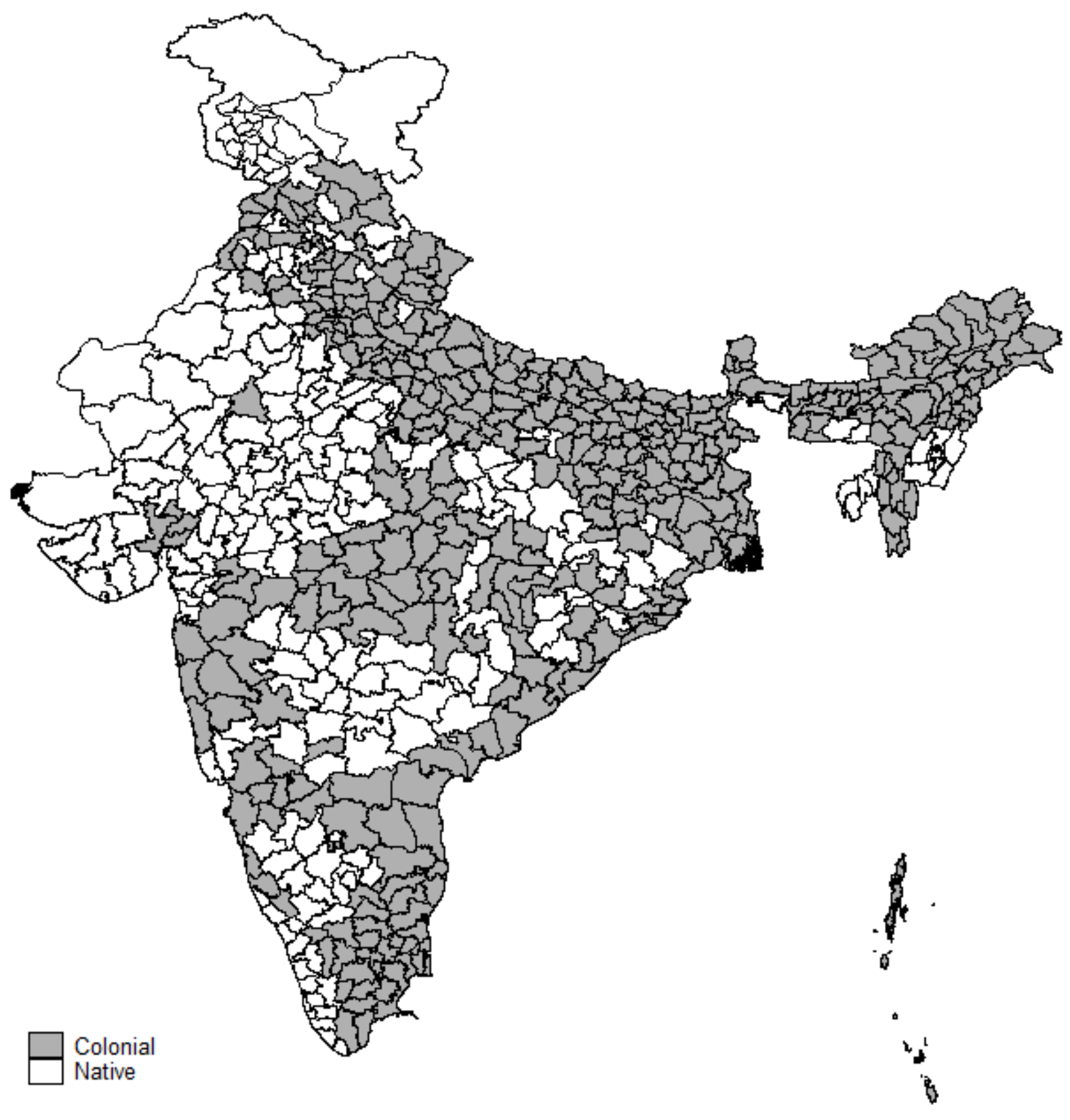


Such classification of territories into British and Native ruled areas, led to differences in policies, but also in political participation and literacy, among other things. The British areas were more exposed to politics due to factors like participation in the Provincial Elections of 1919, 1935 and $1946 . .^{5}$ The British areas also saw the rise of the political parties (for example the Indian National Congress (INC)) and several of its higher educational institutions became the hotspots of nationalist movements. The native states on the other hand chose to stay away from the mainstream politics and freedom movement due to fear of irking the British, which could affect their autonomy and international relations adversely. Native states like Hyderabad banned the INC and the Rajputana states, for example, were poorly integrated politically (Rudolph and Rudolph, 1966).

\section{Land Tenure System}

Another important aspect of the colonial history of India is the land tenure system instituted by the British to enable collection of land revenues. The British established five kinds of tenure system- Permanent Settlement/ Zamindari, Ryotwari, Taluqdari, Mahalwari/Village Settlement, Malguzari Settlement (Baden-Powell 1892). These five kinds of tenure structure differed vastly both in terms of revenue collection as well the political and social power structures.

In the Zamindari/Permanent Settlement, the landlord acted as the middleman, collecting revenue from the peasants to give them to the British administration. They wielded enormous political clout and were often extractive, charging tax rates higher than those prescribed by the British. The Taluqdari settlement was quite similar the Zamindari

\footnotetext{
${ }^{5}$ Even though the provincial elections were based on restricted franchise.
} 
System, the former was prevalent in the Oudh region (present day Uttar Pradesh) whereas the latter in the Bengal Presidency areas. At the other end of the spectrum was the Ryotwari Settlement, followed in Bombay Presidency and parts of Madras Presidency. Under this system, every cultivator was individually responsible to pay the land revenue directly to the Government and there were no intermediaries. ${ }^{6}$ Malguzari Settlement in the Central Provinces is a combination of the two contrasting tenures, Zamindari and Ryotwari and is also called 'artificial tenure' where the landlords had limited control over the peasants. In the Village/Mahalwari Settlement, the tax burden was shared amongst the village community, where the entire communities as a whole were responsible to pay revenue to the British, but each cultivator-villager was personally obligated to contribute a share to the total amount. This system, though difficult to administer was prevalent in the North-Western Provinces and Punjab. In this paper, I classify Taluqdari and Zamindari Settlement as landlord tenure and all the rest as non-landlord tenured areas (discussed in detail in Section 4). ${ }^{7}$ Figure 2 presents the land tenure system followed across India as classified by A.Banerjee and Iyer (2005).

\footnotetext{
${ }^{6}$ Bombay Presidency represents present day Maharashtra, parts of Karnataka and Gujarat. Madras Presidency represents present day Tamil Nadu and parts of Karnataka.

${ }^{7}$ Research shows that over the years, the different types of land tenure has gone through a lot of conversion and has become intermixed. Some scholars opine that all the land tenures, tended to towards the Zamindari system (Gohit 2007).
} 


\section{Figure 2: Spatial Distribution of Land Tenure in India}

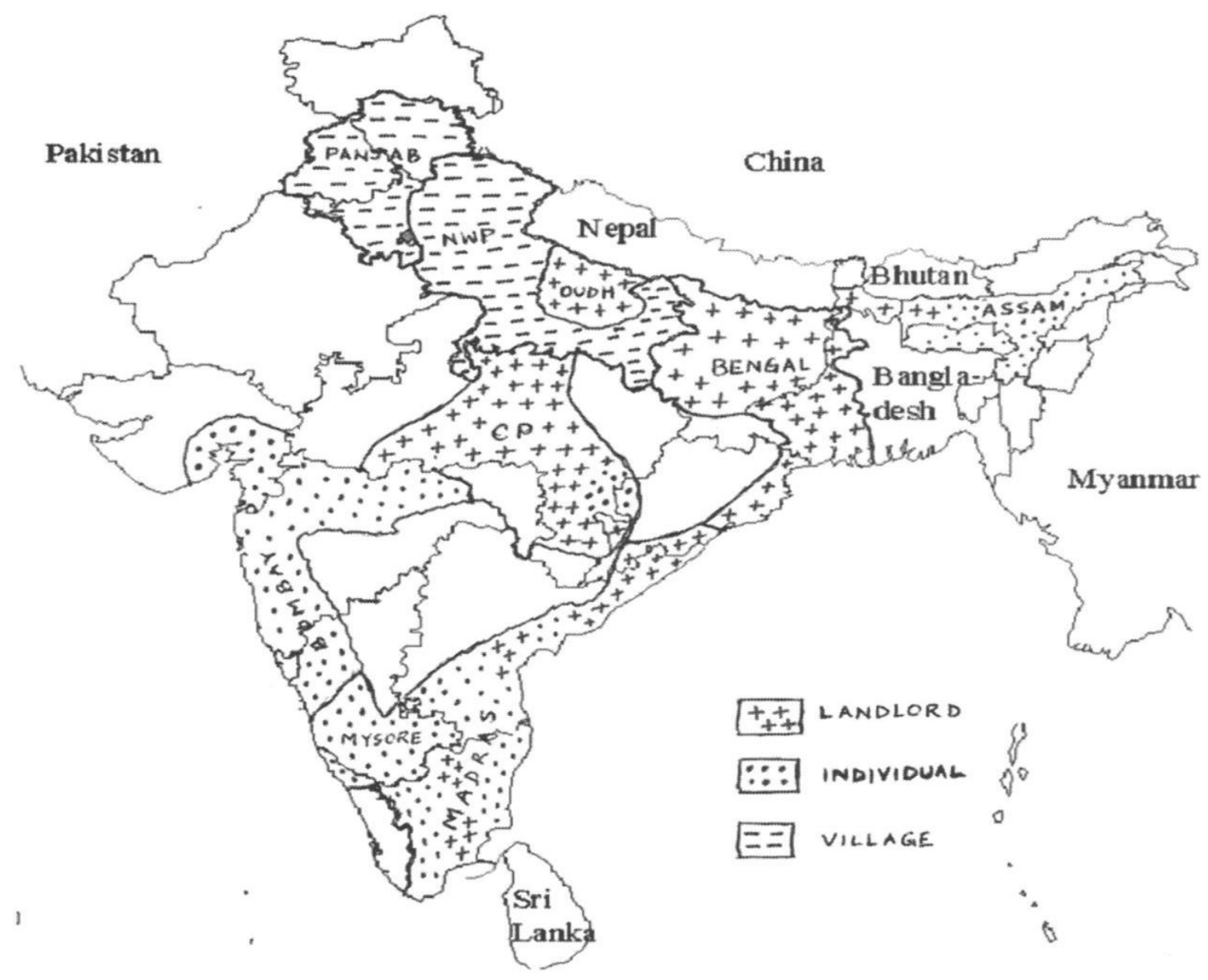

Source: Banerjee, Abhijit, and Lakshmi Iyer. 2005. "History, Institutions, and Economic Performance: The Legacy of Colonial Land Tenure Systems in India." American Economic Review 95 (4): 1190-1213. 
Research shows that non-landlord areas tend to have better public good facilities than the landlord areas, because the landlords were content earning the land revenue and were not motivated to improve the land or invest in public goods (A.Banerjee and Iyer 2005). In terms of agricultural productivity, both the Zamindari and Ryotwari were similar in the early 1900s but the productivity in the former improved in comparison to the latter in 1930s (Kapur and Kim 2006).

\section{Colonial legacies and electoral outcomes}

How might colonial legacies relate to electoral outcomes? Overall, differences across native and British territories could result in persistent differences in electoral outcomes due to the fact that the latter already had several elements of an electoral process in place, even if in a limited way. At the same time, efforts after Independence, to bring all the princely states under the umbrella of a single government could have weakened or erased these differences. One such initiative was the creation of the voter list by the Constituent Assembly (CA) and Election Commission. Shani (2017) describes the efforts on the part of the CA to include all the individuals in the voting process to compile a conclusive voter list, with special care taken to create guidelines to deal with the significant migration to and from the country. Such efforts likely attenuate differences between the colonial and native rule by establishing universal adult franchise in newly independent India. In matters of literacy, the native states were heterogeneous, the literacy levels of the Travancore state, for example, was higher than most other native states, even higher than the British territories (Iyer 2004) and could well have had a similar attenuating effect. 
Land tenure, as a colonial legacy, on the other hand, shaped the political dynamics in the rural areas. Distribution and ownership structure of land potentially affects voting patterns as the political interests of rural elites and peasants most often do not match (A. Banerjee and Iyer 2005). Several instances of mobilization of peasants for insurgency, example, Maoism in Nepal and India (Brass 1994; Joshi and Mason 2007), Naxalbari Movement in West Bengal (Gough 1974; Mukherji 1987) and the related uprisings like the Shahada Movement owe their roots to the hegemony of the tenure system (Mies, 1976). ${ }^{8}$ Exploitation of peasants by the landed, have often led to a 'class-based resentment' and formation of political parties to put forward their demands. ${ }^{9}$ Despite the Government of India's initiative to abolish the landlord regime in the 1950s, the continued power of the landed class in agrarian society continues to play a significant role in deciding electoral and political outcomes (Wiener 2013). ${ }^{10}$

\section{Empirical Strategy}

As mentioned earlier, cross-country comparison of colonial legacies is often difficult, owing to the systematic differences in institutions (Lankina 2014). An ideal unit of analysis would be a nation-state, which has previously been under native and foreign rule contemporaneously. India offers an ideal example in this situation, as India housed both Direct and Indirect rule in the country, as well as multiple land tenure systems within colonial territories. A comparison between these territories, even though we have no

\footnotetext{
8 Joshi and Mason (2007) attribute the rise of Maoism in Nepal to the feudal land tenure system, where the "landed" elites reigned over the poor peasants and thus lead to the spread of wide discontent among the peasants.

9 Examples of such current class struggles in the form involvement of peasants in the Naxalite and Maoist movements have their roots in the tenure structure (Brass 1994).

10 Refer to Besley and Burgess (2000) for more details on land reform acts.
} 
counterfactual outcomes in the case of British not setting any institutions in the country, could be attributed to differential effects of the rule on electoral outcomes (Iyer 2004).

However, there could be non-random allocation of territories between the two major regimes i.e. British and Princely states. In other words, there may exist systematic differences in the type of territories under each rule, as British may have annexed the more agriculturally productive areas (Iyer 2004). This may result in the presence of selection bias in the annexation of territories by the colonizers.

I address this potential endogeneity in two ways. The first approach deals with controlling for as many factors as possible that could be systematically different between the colonial and the native states, which could also impact the electoral outcomes possibly leading to omitted variable bias. ${ }^{11}$ These include literacy rate, population (total and rural), religious and political identities. Religious and caste identities play a significant role in the electoral politics of India, studies have shown an increase in the voter turnout when seats are reserved for the backward classes (Jaffrelot 1999 ; Mori and Kurosaki 2016). Electoral participation is higher in rural areas in comparison to its urban counterparts, owing to greater social cohesion in the former (M. Banerjee 2007; 2011). As for literacy, while some scholars have found that "exogenously induced change in high school graduation rates have powerful effects on voter turnout rates" others claim that an additional year of schooling has very little impact on the voter turnout (Tenn 2007). This set of controls likely account for most of the endogeneity (refer to Table A1 and Table A2 in the Appendix for descriptive statistics).

11 Even though the literature discusses mostly about the voter turnout theory, the other two electoral variables - margin of victory and number of candidates contesting elections can be explained by the same set of variables 
To address any further concerns on endogeneity, I follow Iyer (2004), A. V. Banerjee and Iyer (2008) and use instrumental variables for each of the two colonial institutions. ${ }^{12}$ As with Iyer (2004), I use the death of a ruler, between 1848 and 1856, without a natural heir, as an instrument for colonial institution. Lord Dalhousie in 1848 used this as an argument to annex native territories and is popularly known in history as the Doctrine of Lapse. ${ }^{13}$ The native states annexed under this Doctrine remained a part of the British territories till Independence. The validity of the instrument is maintained by the assumption that the death of the ruler in 1800s does not affect electoral outcome in the 1950s directly but only via its correlation with British rule. ${ }^{14}$ To address endogeneity of land tenure, I use annexation by British between 1820 and 1856 as an instrument for nonlandlord districts. Most of the annexed territories of this time were subject to non-landlord tenure, example the Ryotwari system was implemented in Madras around 1820s and historical accounts suggest no selectivity in which territories were assigned what kind of tenure (Iyer 2004). The period of annexation is unlikely to have a direct impact on electoral outcomes other than via variables that are already included as controls and accounted for in the analysis.

Endogeneity is likely a more serious concern with the outcomes other scholars have evaluated, such as agricultural output or public goods provision, than it is perhaps for

\footnotetext{
12 Iyer (2004) evaluates the impact of colonial rule on agricultural investment and public good provisioning; the potential cause of endogeneity arises here, because the rulers could have been systematically annexing agriculturally fertile territories. Such an incident will result in the biased estimate of the causal impact of colonial rule.

${ }^{13}$ Lord Dalhousie served as the Governor-General of India from 1848 to 1856.

${ }^{14}$ For further details about the instrument, please refer to Iyer (2004)
} 
electoral outcomes. ${ }^{15}$ I still use the IV regressions in addition to my assumption of accounting for all observable differences.

In the regression equation, I use an interaction between the colonial and nonlandlord variable, to capture the impact of colonial institutions through the land tenure system instituted by the British as the data on land-tenure is only available for areas under British rule. ${ }^{16}$

The Least Squares (LS) regression studying the impact of colonial rule and land tenure on electoral outcomes is given below:

$$
\begin{aligned}
& Y_{d t}=\alpha+\beta_{1} \text { COLONIAL }_{d}+\beta_{2} \text { COL_NONLANDLORD }_{d}+\beta_{3} \text { Literacy }_{d t}+ \\
& \beta_{4} \text { TotPOP }_{d t}+\beta_{5} \text { UrbanPop }_{d t}+\beta_{6} \text { FragmentationIndex }_{d t}+
\end{aligned}
$$

$\beta_{7}$ Share of Disadvantaged Section $_{d t}+\varepsilon_{d t}$

In case of the instrumental variable- two stage least squares (IV-2SLS) regression, the first stage regressions used are given below:

COLONIAL $_{d}=\alpha_{1}+\alpha_{2}$ rulerdeat $_{d}+\alpha_{3}$ Literacy $_{d t}+\alpha_{4}$ TotPOP $_{d t}+\alpha_{5}$ UrbanPop $_{d t}+$ $\alpha_{6}$ FragmentationIndex $_{d t}+\alpha_{7}$ Share of Disadvantaged Section $_{d t}+\mu_{d t}$

COL_NONLANDLORD $d=\gamma_{1}+\gamma_{2}$ annexation $_{d}+\gamma_{3}$ Literacy $_{d t}+\gamma_{4}$ TotPop $_{d t}+$ $\gamma_{5}$ Urban Pop $_{d t}+\gamma_{6}$ Fragmentation Index $_{d t}+\gamma_{7}$ Share of Disadvantaged Section St + $\delta_{d t}$

\footnotetext{
15 The possibility of a reverse causation is not applicable here as the administrative identity of districts precedes any post-Independent event and is invariant over time. Moreover, issues like campaign finance are unlikely to be affecting the early elections post-Independence.

${ }^{16}$ Detailed description of the tenure structure implemented by the British is found in the works of BadenPowell (1892), however no such information source is readily available for the princely states. Thus in this paper I compare only the tenure system under the British colonial areas.
} 
The dependent variables are electoral outcomes, namely, voter turnout, margin of victory and electoral competition. The analysis is conducted for the general elections of 1951 (representing short run) and elections of 1971, 1977 (representing long run). The controls, to account for factors affecting electoral outcomes are, literacy rate, total population, urban population, share of individuals belonging to disadvantaged sections (Other Backward Caste/Scheduled Castes/ Scheduled Tribes) and an index for religious fragmentation.

In equation (ii), the colonial variable is instrumented by the death of a ruler in the native states, between 1848-1856, without leaving behind a natural heir. In equation (iii), tenure structure followed in the colonial territories is instrumented by the dummy variable "annexation", which records if the territory was annexed by the British, between 18201856.

The direction of impact of colonization on voter turnout is ambiguous. The higher political participation and awareness of colonial states due to opportunity to vote for the Provincial elections (1919, 1935, and 1946), greater number of government offices, and higher number of government run higher education institutions could result it to have higher voter turnouts. On the other hand, some of the native states like Travancore and Baroda, were quite progressive in their policymaking and people were abreast of all political movements in the country. Heterogeneity in the territories coupled with the motive of eliminating colonial legacies post-Independence, by the creation of the voter list leads to the hypothesis that the sign of $\beta_{1}$ coefficient could be either positive or negative. 
As for land tenure, in the early years, close to Independence, the persistence of the land tenure and its deep-rooted influence on the socio-economic dynamics of the country may differentially affect electoral outcomes. I expect a positive impact of non-landlord areas on voter turnout, i.e. $\beta_{2}>0$. Such positive impact follows from the paternalistic ties between the landlord and his tenants in the landlord dominated areas, where the former may threaten to withhold support to the latter in case they decide to cast their vote to a party supporting tenure reforms (Joshi and Mason 2007; Beg 2016). The impact of tenure on voter turnout is expected to attenuate over the years reflecting the implementation of the tenure reforms in the 1950s.

The direction of impact of both the colonial institutions on margin of victory is uncertain as the spread of INC in both the native and direct ruled states post-Independence reduced the inherent differences in the level of political activity in these states. On the other hand, despite the spread of INC in both the erstwhile colonial and native areas postIndependence, the former were disproportionately more involved in the freedom struggle and associated politics. This could lead to higher electoral competition in the colonial areas. The direction of land tenure on both margin of victory and electoral competition is uncertain.

To analyze the total impact of colonial institutions on the dependent variable, I test whether linear combination of coefficients of the focal variables i.e. $\beta_{1}+\beta_{2}$ is equal to zero. In next section, I discuss the data sources and the constructs used in this paper. 


\section{Data Sources and Methods}

\section{Electoral Data and Methodology}

All electoral data are sourced from the detailed election reports published by the Election Commission of India (ECI). Voter turnout is computed as the share of voters who have voted in the total electorate. Margin of victory is defined as the difference in votes between the winner and the runner's up as a proportion of total number of voters. I define electoral competition as the number of candidates contesting elections, this variable is not normalized by voter population, because the delimitation of constituencies tries to achieve almost similar population size in the constituencies across a state. ${ }^{17}$

Electoral data is available only at the constituency level. Converting constituency level data into district level data or vice versa is a challenging task due to lack of fit between the two (Alam 2010). ${ }^{18}$ There are two ways to deal with this problem, the first one involves "centering" each constituency to the district it belongs to, and this approach creates a district level database. The second approach is to super-impose the GIS maps of Indian parliamentary constituencies on the map of India and use area-weighted district characteristics to form a constituency database. ${ }^{19}$ In this paper, I have "centered" each

\footnotetext{
17 The other method to evaluate the electoral competition is by calculating the effective number of parties $(E N P)=1 / \sum\left(p_{i}^{2}\right)$; where $p_{i}$ is the share of votes received by political party ' $i$ '. In this paper I conduct the analysis at a further granular level, the number contestants. In the earlier elections, the number of state and national level political parties was still very low and a party could field more than one contestant from a constituency. In such a case the ENP is not a good representative of the competition as it accounts for the parties and not the individuals standing for elections.

18 The district-constituency match is very low, some districts have more than one constituency, while some constituencies span over multiple districts.

${ }^{19}$ This method is difficult to implement, due to absence of a map demarcating all the parliamentary constituencies for the elections of 1951 especially.
} 
constituency to the district it belongs to, based on the district list in the corresponding decade's Census.

In case, a district has more than one constituency I aggregate the constituency level electoral data (for respective electoral variables) belonging to that district. But if a constituency spans more than one district, there are multiple approaches to align the two data. ${ }^{20}$ In this paper, I divide the constituency level electoral data by the number of districts it spans and then attribute the divided data to the respective districts. This approach assumes equal proportion of voters and electorate being apportioned to the districts the constituency spans over. Each of the methods has their own limitations. I prefer this method over the others as the chances of statistical constructs affecting the outcomes is the lowest. I follow the same process for the outcome variable margin of victory.

The analysis is done at a district level as district boundaries have more or less remained the same, even though state boundaries have undergone several changes under The States Reorganization Act, $1956 .{ }^{21}$ The analysis takes into account multi-member constituencies, which were present up until 1962. [22]

For electoral competition, I use a slightly different approach. In this case if a constituency spans multiple districts, then the same number of candidates is assigned to

\footnotetext{
20 There are three approaches to deal with the non-alignment of the administrative units with the constituencies. Each of these methods has their own limitations. I have estimated the results using all the three approaches and they are mostly consistent. Please contact the author for more details.

${ }^{21}$ Due to this Act, there is a lack of fit between the electoral data of 1957 and the Census of 1951 . While the election data is based on the state list created after the Act, Census of India, 1951 does not capture this. This aggravates the already existent problem of lack of district-constituency fit. The "centering" of 1957 constituencies on the district list of 1951 Census may cause errors in interpretation. In my analysis, to maintain continuity in analysis I have estimated the results but I have refrained from presenting and interpreting them, owing to the statistical discrepancies underlying it. But those interested may contact the authors for the same.

${ }^{22}$ http://eci.nic.in/eci main1/parliament.aspx retrieved on 10 $0^{\text {th }}$ May, 2018
} 
each district that the constituency spans over, as each voter faces the same choice of candidates in each constituency.

\section{Colonial Rule and Land Tenure}

Classification of each district into colonial or native was done using the archival maps of Imperial Gazetteer of India $(1909,1931)$. Districts those were predominantly under the native rule are recorded as zero and those under direct British rule are recorded as one. ${ }^{23,}$

Data on land tenure followed in different parts of the country come from BadenPowell (1892), the most authoritative source available on colonial land tenure. I construct a binary variable taking the value zero for landlord tenure, and one otherwise. Zamindari and Taluqdari settlement form a part of the landlord tenure system. All the other forms of tenure system, namely Ryatwari, Mahalwari, Malguzari, Village settlements and temporary settlements have been classified as non-landlord. ${ }^{25}$ Information on tenure is available only for the areas that were under British administration and I set the value for the land tenure variable to be zero in case of native ruled districts (A. Banerjee et. al. 2005). [26] [27]

\footnotetext{
${ }^{23}$ If a district had the presence of both forms of rule, the principle of majority is followed, where; the rule dominating the major share of the geographical area is attributed to the district.

${ }^{24}$ http://dsal.uchicago.edu/reference/gazetteer/, as accessed on 9th May,2018

${ }^{25}$ Here, I am following a mix of classification systems used by A. Banerjee and Iyer (2005), V. Iversen, Palmer-Jones, and Sen, (2013) and Roy (2014).

${ }^{26}$ However, in this analysis, unlike A. Banerjee et. al. (2005) I classify the Central Provinces as non-landlord areas based on the information provided by Baden-Powell (1892), where it describes the land tenure in CP to be "artificial" and combines features of landlord and non-landlord system. Under this tenure (Malguzari Settlement), the proprietary rights to land were variable, indicating full proprietary rights were owned by some landlords and none by some. Owing to the mixed nature of this tenancy, I classify them under nonlandlord system.

${ }^{27}$ Roy (2014) critiques the methodology used by A. Banerjee et al. (2005), due to the discretion used by the authors, to classify the districts into landlord/non-landlord land tenure systems. V. Iversen et al. (2013) too
} 
Data on literacy rate, population (total and rural), religious and caste diversity are from Census 1951 and 1971. Literacy rate is computed by dividing the number of literates by the total population. Caste divisions are accounted for by taking the share of disadvantaged section (Scheduled caste, Scheduled Tribe and Other backwards Castes) in total population. For religious diversity, I construct a fragmentation index as used in A. Banerjee and Somanathan (2001). The fragmentation index is computed using the formula $1-\sum \mathrm{s}_{\mathrm{i}}{ }^{2}$ where, $\mathrm{s}_{\mathrm{i}}$ is the share of the group in the total population. 2829

I control for state fixed effects and estimate the regressions with and without bootstrapped standard errors to account for the very few observations for which the IV identifies the effects. However, the state effects coincide with the colonial rule and hence I estimate equation (i).

\section{Results and Discussion}

Tables 1, 2 and 3 show the results of the regression I estimate for equation (i). ${ }^{30} 31$ The test for endogeneity of the IV Model suggests an absence of endogeneity. I therefore focus on I and interpreting the least squares model for the rest of the paper.

The regression results, for the primary outcome variable, voter turnout (VT), indicates that in the short run, there no statistically significantly difference across the two kinds of territories possibly due to the inclusive efforts made by the CA while preparing the

contests the A. Banerjee et al. (2005) classification with respect to the designation of the Central Provinces as landlord areas.

28 Refer to A. Banerjee and Somanathan (2001) for greater details .

29 The state fixed effects coincides with the colonial land tenure and hence I use this model.

${ }^{30}$ I consider results to be robust for level of significance is $5 \%$ or lower.

31 Given the few observations classified as valid as instruments, I have bootstrapped the standard errors and the results remain unchanged. 
voters list, which may have negated any pre-existing differences (Table 1). However, on an average, 4\% higher VT in the native areas, in the long run (elections of 1970s) can be explained by the increased involvement of the erstwhile princes in the political arena. During this time, political parties sought out the princes, for their large vote banks (Richter and Ramusack 1975). These princes were often descendants of old and well-respected ancestral families. Even though the kingdoms were non-existent, the members of the royalty were still revered by the locals. Political parties exploited this sentiment and persuaded the princes to contest elections. The total number of contestants from the princely states saw an abrupt increase in the elections of 1967 and continued into the elections of 1970s (Richter 1971). The early 1970s saw another event that led to greater participation of princes in political spheres. During the integration of the native states into the union of India, several state rulers were entitled to 'privy purses' - a yearly payment in lieu of stepping down from the throne and joining the Indian union (Baxi 1990). In 1971, the government abolished these privy purses. To safeguard their monetary interests, many princes joined politics (Richter and Ramusack 1975). Private institutions like "Consultation of Rulers of Indian States" was setup post 1967, to foster unity and act upon common interests of the princes. Gradual politicization of the princes also possibly improved the voter turnout in these areas, owing to the sentiments of public towards the princes. In many cases, as a mark of respect towards the princes standing in the elections, other candidates were not likely to enter the fray or even prefer to withdraw candidature fearing imminent defeat (Richter 1971; Richter and Ramusack 1975). I test whether this is a plausible explanation in a later section. 
In contrast to colonial rule, the type of tenure has short term impact on VT (Table 1). Non-landlord areas have 5\% higher VT on average than landlord areas in the short run, consistent with the findings of Joshi and Mason (2007) and A. V. Banerjee and Iyer (2008). But the impact dissipates in the longer run. The short term impact of the tenure system on the VT can be attributed to the inertia of social institutions, where feudalism was still in play as the land reforms came into force with a delay (Besley and Burgess 2000; Bowles, Choi, and Hopfensitz 2003). The strong clientele relations between the landlord and the peasants in the feudal areas forces the latter to refrain from participating in the electoral process due to the fear of landlords withholding support in forms of credit, land access and others in order to prevent peasants from voting for political parties advocating tenurial reforms (Joshi and Mason 2007). But effective enactment of reform measures perhaps weakened such channels; the impacts of tenure structure thus dissipate over time (Ghatak and Roy 2007).

In order to evaluate the total impact of colonial institutions, I test the linear combination of the coefficients of the colonial and land tenure variable. I find no impact of the institutions in the short run but see a significantly higher VT in the native areas in the elections of 1970s, suggesting that the type of rule dominates tenurial legacies (Table 4).

For margin of victory (MV), I find no short run impact of colonial rule on margin of victory (MV). However, the elections of 1977 sees an average of $14.4 \%$ higher MV in the erstwhile colonial areas (Table 2). ${ }^{32}$ This can be explained in the light of the National Emergency of 1975, when the then ruling party Indian National Congress was ousted from

\footnotetext{
32 The MV variable accounts only for the difference in vote shares and is devoid any information about the political scenario of the times.
} 
power in the following elections of 1977, owing to the mass protest against the suspension of liberties, atrocities committed against citizens among various other things. This led to a landslide victory of the opposition and the formation of the first non-Congress government in the Centre. In the long run, this correlates with the direct rule as these areas developed into metropolitan cities and the political hotbed for protests against the government in the post-colonial times. Historically prominent areas like Calcutta, Bombay, Allahabad which were all under direct colonial rule saw a major reversal in power in the elections of 1977 as agitations, demonstration against the Congress (for promulgation of Emergency) gained ground and opposition developed deep roots here. [33] [34] [35] [36] The elections of 1977 saw a fall in the seat shares of Congress by approximately 55\%.37 I test this conjecture in a later section.

I find no impact of land tenure on MV in either short or long run. ${ }^{38}$ The total impact of colonial institutions on MV is significantly higher in the colonial areas in the elections of

\footnotetext{
33 Justice Sinha, who set aside Indira Gandhi's election, dies at 87 - Express India. (2012, March 9). Retrieved June 27, 2018, from https://web.archive.org/web/20120309151210/http://www.expressindia.com/latestnews/aajustice-Sinha-who-set-aside-Indira-Gandhis-election-dies-at-87/287227/

${ }^{34}$ Jayaprakash Narayan was a strong opponent, with the moral authority that Indira Gandhi lacked. (2018, June 25). Retrieved June 27, 2018, from https://theprint.in/pageturner/excerpt/jayaprakash-narayan-was-astrong-opponent-with-the-moral-authority-that-indira-gandhi-lacked/74627/

35 The JP Movement and the Emergency: Indian Democracy Tested - India Since Independence. (n.d.). Retrieved June 27, 2018, from https://erenow.com/exams/indiasinceindependence/20.html

36 EMERGENCY SPECIAL. (2010, February 11). Retrieved June 27, 2018, from https://web.archive.org/web/20100211074251/http://www.indianexpress.com/ie/daily/20000713/e1.ht $\underline{\mathrm{m}}$

${ }^{37}$ Authors calculation based on ECI reports

38 The significance of the colonial -non-landlord variable in the elections of 1951 is not robust to specification changes and the results are sensitive to the clubbing of the disadvantaged sections of the population. On dividing the share of disadvantaged section into the share of SC, ST and OBC, the significance of the colonialnon-landlord variable no longer holds. Other model specifications included incorporation of number of candidates, and its interaction with the non-landlord term to help explain the significance of colonial-nonlandlord variable. But in all the specifications the added variables had poor explanatory power with no significant impact.
} 
1971 and 1977, likely owing to the peaking of Congress popularity in the former and its rapid decline in the latter (Table 4). ${ }^{39}$

My third variable of interest is the electoral competition (EC) measured by the number of candidates contesting election. Results indicate significant positive impact of colonial institutions on EC in both short and long run (Table 3). The election of 1951 (short run) sees an average of three contestants more in the colonial area, which increases to five in the elections of 1970s (longer run). These results can be explained in light of advantage of higher political awareness and participation of the erstwhile British areas in comparison to native states, during the time period closest to the Independence. One reason could be the prior exposure of these areas to the concept of elections in the form of Provincial elections of 1919, 1935 and 1946, even though it involved restricted franchise.

Also, most colonial states were involved in the mainstream politics of Independence movement, unlike the native states who were unwilling to enter this debate due to fear of irking the British. Such reasons combined with the fact that post-Independence several erstwhile colonial areas had become state capitals housing state secretariats and were hosting a large number of higher educational organizations instituted during the British era, which possibly led to the increase in the political knowledge base, allowing people to grasp the spirit of democracy and leading them to contest elections in greater numbers.

Many princely states on the other hand, were cloistered and cut off even in the early post-Independence period as they had recently been integrated into the Dominion of India.

\footnotetext{
39 The elections of 1971 saw the popularity of Congress leader Indira Gandhi at rise, with popular slogan of Garibi Hatao. The elections of 1977 saw the polar opposite, where the promulgation of the Emergency led to countrywide dissent against the Congress rule (except the states of Tamil Nadu and Kerala)
} 
They were trying to carve out an identity for themselves, while combating internal political strife for power (e.g. Hyderabad, Kashmir, Junagadh), as internal conflicts subsided, erstwhile princes joined mainstream politics and started contesting elections. But recognition of princely lineage is likely to have deterred common man from contesting elections from the same area as the princes, thus reducing electoral competition in the native states in the later years. 
Table 1: Impact of Colonial Institutions on Voter Turnout

Dependent Variable: Voter Turnout

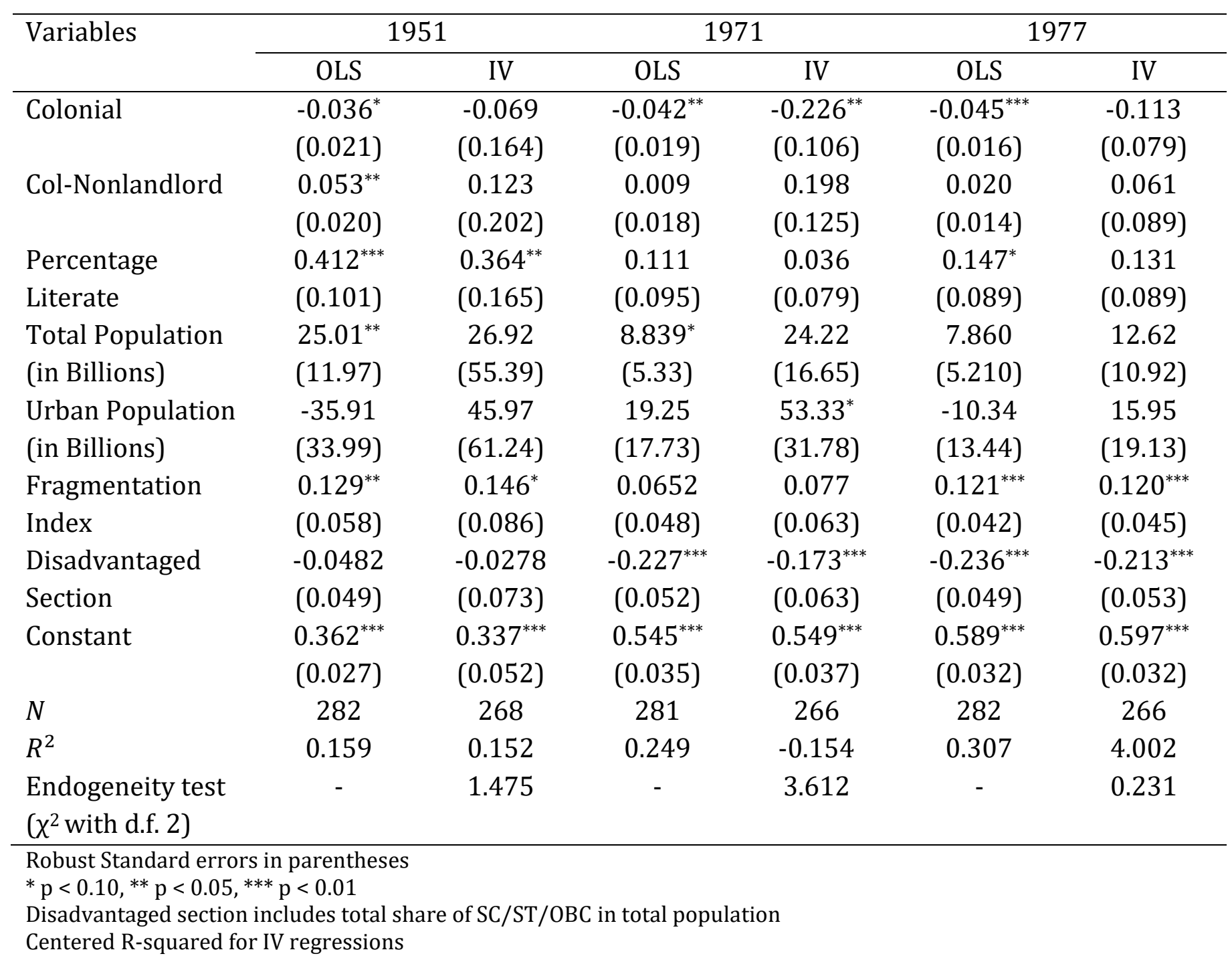


Table 2: Impact of Colonial Institutions on Margin of Victory

Dependent Variable: Margin of Victory

\begin{tabular}{|c|c|c|c|c|c|c|}
\hline \multirow[t]{2}{*}{ Variables } & \multicolumn{2}{|c|}{1951} & \multicolumn{2}{|c|}{1971} & \multicolumn{2}{|c|}{1977} \\
\hline & OLS & IV & OLS & IV & OLS & IV \\
\hline \multirow[t]{2}{*}{ Colonial } & -0.023 & -0.004 & 0.009 & -0.056 & $0.144^{* * *}$ & 0.042 \\
\hline & $(0.021)$ & $(0.220)$ & $(0.027)$ & $(0.206)$ & $(0.045)$ & $(0.210)$ \\
\hline \multirow[t]{2}{*}{ Col-Nonlandlord } & $0.039^{* *}$ & 0.053 & $0.046^{*}$ & 0.257 & $-0.065^{*}$ & 0.0328 \\
\hline & $(0.019)$ & $(0.262)$ & $(0.026)$ & $(0.243)$ & $(0.039)$ & $(0.246)$ \\
\hline Percentage & 0.107 & 0.108 & -0.002 & -0.070 & -0.132 & -0.138 \\
\hline Literate & $(0.088)$ & $(0.198)$ & $(0.041)$ & $(0.088)$ & $(0.183)$ & $(0.207)$ \\
\hline \multirow{2}{*}{$\begin{array}{l}\text { Total Population } \\
\text { (in Billions) }\end{array}$} & $-30.16^{* *}$ & -43.03 & 2.377 & 13.04 & -3.205 & 3.809 \\
\hline & $(12.05)$ & (71.61) & $(8.256)$ & $(20.27)$ & $(4.689)$ & $(21.31)$ \\
\hline \multirow{2}{*}{$\begin{array}{l}\text { Urban Population } \\
\text { (in Billions) }\end{array}$} & 3.899 & 73.92 & $-27.07^{*}$ & -36.40 & -11.59 & -29.28 \\
\hline & $(30.67)$ & $(64.40)$ & $(16.01)$ & $(25.94)$ & $(24.00)$ & $(36.50)$ \\
\hline Fragmentation & 0.015 & 0.004 & -0.072 & -0.079 & -0.093 & -0.082 \\
\hline Index & $(0.053)$ & $(0.090)$ & $(0.071)$ & $(0.082)$ & $(0.082)$ & $(0.0761)$ \\
\hline Disadvantaged & -0.087 & -0.074 & $-0.307^{* * *}$ & $-0.233^{* * *}$ & 0.159 & -0.023 \\
\hline Section & $(0.056)$ & $(0.088)$ & $(0.056)$ & $(0.082)$ & $(0.180)$ & $(0.0783)$ \\
\hline \multirow[t]{2}{*}{ Constant } & $0.207^{* * *}$ & $0.196^{* * *}$ & $0.326^{* * *}$ & $0.271^{* * *}$ & $0.241^{* * *}$ & $0.290^{* * *}$ \\
\hline & $(0.026)$ & $(0.058)$ & $(0.033)$ & $(0.043)$ & $(0.069)$ & $(0.059)$ \\
\hline$N$ & 280 & 266 & 279 & 264 & 282 & 266 \\
\hline$R^{2}$ & 0.071 & 0.075 & 0.100 & -0.1 & 0.104 & 0.073 \\
\hline $\begin{array}{l}\text { Endogeneity test } \\
\left(\chi^{2} \text { with d.f. } 2\right)\end{array}$ & - & 0.517 & - & 7.683* & - & 0.107 \\
\hline \multicolumn{7}{|c|}{$\begin{array}{l}\text { Robust Standard errors in parentheses } \\
{ }^{*} \mathrm{p}<0.10,{ }^{* *} \mathrm{p}<0.05,{ }^{* * *} \mathrm{p}<0.01\end{array}$} \\
\hline
\end{tabular}


On the other hand, non-landlord areas have negative impact on the EC, landlord on an average have 1.7 candidates more than non-landlord territories, which increases to 3.6 in 1971 and 4.7 in 1977 elections (Table 3). The short term result is consistent with the findings in A. V. Banerjee and Iyer (2008) and could possibly be a result of efforts on the part of the then political parties, to dismantle the feudal system by pitching more candidates from landlord dominated areas (in some constituencies, several political parties nominated more than one candidate for a given seat). However, the claim is hard to test empirically and needs further research.

In the longer run however, the significance of the colonial-non-landlord variable owes its explanation to the ongoing political happenings in these areas rather than the tenure structure. The areas coded as predominantly landlord are, Bengal Presidency, United Provinces and Oudh which corresponds to present day West Bengal, Bihar and Uttar Pradesh. Each of these states was undergoing political upheaval during and following the course of Emergency, resulting in the rise of anti-Congress sentiments. ${ }^{40}$ Anecdotal evidence and newspaper articles mentions several crackdowns being conducted in West Bengal, during the Emergency period which was vehemently resented by the public, such growing dissent led to the rise of new political alternatives in the form of candidature and parties. ${ }^{41,42,43}$

\footnotetext{
${ }^{40}$ It is to be noted here that, the results still hold after clustering on the basis of state boundaries.

41 The ruling party in Bengal was Indian National Congress, and the then Chief Minister of Bengal was considered as an important aide of the Prime Minister, Smt. Indira Gandhi, who promulgated the Emergency. The opposition, Left Front also known as the Communist Party of India, too was in support of the Emergency. This left the state in a political flux, which aided new political alternatives to come up to protest the policies of the government.

42 https://www.thehindu.com/books/literary-review/excerpt-from-the-dramatic-decade-the-indira-gandhiyears/article6748577.ece, retrieved on $13^{\text {th }}$ August, 2018
} 
Uttar Pradesh was the hotbed of politics prior to the Emergency and well after. The reason behind the promulgation of National Emergency was considered to be the defeat of the then Prime Minister in the Allahabad High court, on charges of electoral malpractices raised by Raj Narain in the election of 1971. In Bihar, protests against the Congress Raj, popularly known as the JP Movement, began under the leadership of Jayprakash Narayan, which ultimately led to the formation of a political party, Janata Dal, the first non-Congress organization to lead the country.

Such cases of upheaval and the tendency to curb not only personal but also democratic freedom, created an atmosphere of dissent towards the ruling party and encouraged citizens to participate in the electoral process not just as voters but also by contesting elections. Such efforts were made to emphasize the spirit of democracy by utilizing elections as means to protest against the current rule.

${ }^{43}$ https://indianexpress.com/article/india/india-others/six-months-before-emergency-s-s-ray-to-indiragandhi-crack-down-get-law-ready/, retrieved on $13^{\text {th }}$ August, 2018 
Table 3: Impact of Colonial Institutions on Electoral Competition

Dependent Variable: Electoral Competition

\begin{tabular}{|c|c|c|c|c|c|c|}
\hline \multirow[t]{2}{*}{ Variables } & \multicolumn{2}{|c|}{1951} & \multicolumn{2}{|c|}{1971} & \multicolumn{2}{|c|}{1977} \\
\hline & OLS & IV & OLS & IV & OLS & IV \\
\hline \multirow[t]{2}{*}{ Colonial } & $3.473^{* * *}$ & -2.944 & $5.542^{* * *}$ & 3.092 & $5.786^{* * *}$ & -0.726 \\
\hline & $(0.705)$ & $(8.557)$ & $(1.358)$ & $(4.760)$ & $(1.035)$ & $(4.486)$ \\
\hline \multirow[t]{2}{*}{ Col-Nonlandlord } & $-1.727^{* *}$ & 5.486 & $-3.627^{* * *}$ & -2.380 & $-4.679^{* * *}$ & 0.455 \\
\hline & $(0.674)$ & $(9.713)$ & $(1.392)$ & $(4.733)$ & $(1.059)$ & $(5.156)$ \\
\hline Percentage & $-7.648^{* * *}$ & -12.17 & -2.497 & -2.868 & -0.536 & -2.171 \\
\hline Literate & $(2.818)$ & (7.518) & $(3.455)$ & $(4.217)$ & $(1.800)$ & $(3.149)$ \\
\hline Total Population & $2902.7^{* * *}$ & $5163.8^{*}$ & 864.9 & 929.2 & 418.1 & 972.6 \\
\hline (in Billions) & $(385.3)$ & (2727.9) & (781.5) & $(968.2)$ & $(560.3)$ & (987.7) \\
\hline Urban Population & $3545.5^{* * *}$ & -239.5 & $5904.8^{* * *}$ & $7670.0^{* * *}$ & $6530.0^{* * *}$ & $6771.6^{* * *}$ \\
\hline (in Billions) & $(1256.3)$ & $(2517.1)$ & $(1901.7)$ & $(2943.1)$ & $(868.3)$ & $(1751.8)$ \\
\hline Fragmentation & 2.557 & 4.604 & 0.249 & -1.368 & 0.294 & -0.616 \\
\hline Index & $(1.748)$ & $(3.004)$ & $(2.770)$ & $(2.722)$ & $(2.484)$ & $(2.795)$ \\
\hline Disadvantaged & 0.615 & 1.731 & -1.795 & -3.333 & -1.918 & -2.490 \\
\hline Section & (1.034) & (3.045) & $(2.354)$ & (2.184) & $(1.780)$ & $(2.132)$ \\
\hline \multirow[t]{2}{*}{ Constant } & $2.709^{* * *}$ & 1.611 & $4.585^{* * *}$ & $5.819^{* * *}$ & $3.676^{* * *}$ & $5.291^{* * *}$ \\
\hline & $(0.616)$ & $(1.986)$ & $(1.686)$ & $(2.082)$ & $(1.120)$ & $(1.684)$ \\
\hline$N$ & 282 & 268 & 281 & 266 & 282 & 266 \\
\hline$R^{2}$ & 0.496 & 0.246 & 0.426 & 0.404 & 0.543 & 0.323 \\
\hline $\begin{array}{l}\text { Endogeneity test } \\
\left(\chi^{2} \text { with d.f. } 2\right)\end{array}$ & - & 0.739 & - & 0.677 & - & $4.965^{*}$ \\
\hline
\end{tabular}


The total effect of the colonial institutions on EC is significantly for the entire study period, indicating a higher EC in the erstwhile colonial areas. While the results for the latter years owes its roots to the rise of Congress opposition, the results of the 1951 election are likely due the higher political awareness and participation in mainstream politics in the erstwhile colonial areas. All these resulted in higher EC in these areas (Table 4). ${ }^{4}$

Table 4: Total Impact of Colonial Institutions

\begin{tabular}{lccc}
\hline $\begin{array}{l}\text { Dependent } \\
\text { Variables }\end{array}$ & 1951 & 1971 & 1977 \\
\hline $\begin{array}{l}\text { Voter } \\
\text { Turnout }\end{array}$ & 0.016 & $-.033^{* *}$ & $-.025^{*}$ \\
\hline Margin of & -0.017 & -0.013 & -0.013 \\
Victory & 0.018 & $.054^{* *}$ & $.0792^{* * *}$ \\
\hline No. of & -0.019 & -0.023 & -0.023 \\
Candidates & $1.745^{* * *}$ & $1.916^{* * *}$ & $1.108^{* *}$ \\
\hline
\end{tabular}

Robust Standard errors in parentheses

${ }^{*} \mathrm{p}<0.10,{ }^{* *} \mathrm{p}<0.05,{ }^{* * *} \mathrm{p}<0.01$

\section{Pathways of Impact}

In the previous sections, I identified several plausible explanations for the results from quantitative analysis. Owing to the limited availability of data, especially on candidate profiles, it is challenging to uncover the channels through which the impacts of land tenure and colonial rule manifest in electoral indicators. Electoral data only disclose the name and gender of the contestants but does not reveal whether he/she belonged to a royal lineage or whether they are landed or not. The problem of mapping constituency level data to

\footnotetext{
${ }^{44}$ Incidentally these areas were under the feudal system.
} 
districts, owing to the lack of fit, serves as a further limitation. However, I try to overcome the constraints by estimating sub-sample regressions to isolate the impacts of the channels.

In Section 3, I hypothesized that VT is higher in native areas in the 1971 elections due to the entry of princes in the political arena and EC is higher in colonial areas because of rise of opposition against Congress in the colonial areas combined with greater political mobilizations in these areas. In order to test the first hypothesis, I conduct a subsample regression excluding the two erstwhile princely states of Rajasthan and Madhya Pradesh, where there is documented evidence that members of the royal family had begun to participate in the political proceedings and contest elections (Richter 1971). I see that the earlier results no longer hold, suggesting that the two excluded states (Rajasthan and Madhya Pradesh) were indeed driving the results. For the latter case (where EC is higher in colonial states), I exclude the states under colonial rule namely, West Bengal, Bihar, Uttar Pradesh (except Rampur), Tamil Nadu, Maharashtra, Andhra Pradesh and Delhi. ${ }^{45}$ The results indicate the absence of an impact of colonial institutions on EC in the subsample and that the previous results were indeed driven by the erstwhile colonial states (Table 5).

I conduct a similar exercise to examine the hypothesized pathways for the results of the 1977 elections (Table 6). When testing for the pathways for VT, I find that the princely states of Rajasthan and Madhya Pradesh were not the only region where princes were contesting elections, Rampur district of Uttar Pradesh, an erstwhile native state, also saw

\footnotetext{
45 Predominantly colonial areas are West Bengal, Bihar, Uttar Pradesh, Tamil Nadu, Maharashtra, Andhra Pradesh and Delhi. Whereas predominant princely state areas are Rajasthan, Madhya Pradesh, Tripura, Kerala, Gujarat, Orissa and parts of Karnataka (Mysore).
} 
the contestation of elections by members of royal family. [46] I conduct the subsample regression estimation excluding the three aforementioned states, and find no impact of colonial institutions on VT. [47]

The higher MV and EC in colonial areas for the elections of 1977 was attributed to the rise of opposition against the Congress in these areas. I estimate the impact of colonial institutions on MV by taking sub sample of native states and find no impact of it on MV, indicating that the results were being driven by the direct rule states. ${ }^{48}$ Similarly in case of EC, I estimate subsample regression excluding the princely states whose royal lineage was involved in the political spheres along with the states of West Bengal, Bihar and Uttar Pradesh - owing to the political upheaval in these states against the Congress rule. I find no impact of colonial institutions on EC, further bolstering the argument that the omitted states were driving results.

\section{Conclusion}

The above analysis suggests that the historical colonial institutions do have a significant role in shaping political processes and in particular electoral outcomes even after decolonization. Its influence is however not simply that of persistence and is more complex.

\footnotetext{
46 Zulfiqar Ali Khan, the titular Nawab of Rampur, contested elections under various party banners (Swatantra Party and Congress) and won.

47 Because of lack of fit between electoral data and district data, I had to apportion the former amongst the districts it spanned over. Due to this, there exists a difficulty in solely excluding the electoral data of Rampur constituency from the sample. Also, due to spillover effects of the rulers (in this case elected representatives who belonged to the erstwhile royal lineage) in terms of social good provisioning, informal mediation of justice and sheer popularity in the neighboring areas it is unwise to exclude that particular constituency solely. To incorporate the spillover effects and taking into consideration the statistical constraints, I exclude the state of Uttar Pradesh, even though it is predominantly a direct rule area.

48 In this case states of Rajasthan, Madhya Pradesh, Tripura, Kerala, Gujarat, Orissa and parts of Karnataka (Mysore).
} 
In fact, colonial legacies are best seen as moulding contemporary political institutions by modulating responses to interventions that seek to reduce/terminate the existing differences. 
Table 5: Channels of Impact for Elections of 1971

\begin{tabular}{lcc|cc}
\hline 1971 & Dependent Variable: Voter Turnout & Dependent Variable: Electoral Competition \\
\hline Colonial & Full Sample & Sub Sample ${ }^{\mathrm{b}}$ & Full Sample & Subsample $^{\mathrm{c}}$ \\
& $-0.0423^{* *}$ & $-0.0373^{*}$ & $5.542^{* * *}$ & -0.580 \\
Col-Non landlord & $(0.0187)$ & $(0.0213)$ & $(1.358)$ & $(1.448)$ \\
& 0.00901 & 0.0155 & $-3.627^{* * *}$ & -0.174 \\
Percentage Literate & $(0.0184)$ & $(0.0190)$ & $(1.392)$ & $(1.370)$ \\
& 0.111 & 0.115 & -2.497 & -3.222 \\
Total Population & $(0.0947)$ & $(0.105)$ & $(3.455)$ & $(2.870)$ \\
(in Billions) & $8.839^{*}$ & $9.604^{*}$ & 864.9 & $2797.3^{* * *}$ \\
Urban Population & $(5.329)$ & $(5.623)$ & $(781.5)$ & $(562.5)$ \\
(in Billions) & 19.25 & 18.83 & $5904.8^{* * *}$ & $2685.0^{*}$ \\
Fragmentation Index & $(17.73)$ & $(18.46)$ & $(1901.7)$ & $(1410.1)$ \\
& 0.0652 & 0.0515 & 0.249 & -1.889 \\
Disadvantaged Section ${ }^{a}$ & $(0.0481)$ & $(0.0532)$ & $(2.770)$ & $(2.679)$ \\
& $-0.227^{* * *}$ & $-0.215^{* * *}$ & -1.795 & -1.617 \\
Constant & $(0.0517)$ & $(0.0632)$ & $(2.354)$ & $(1.473)$ \\
& $0.545^{* * *}$ & $0.539^{* * *}$ & $4.585^{* * *}$ & $3.227^{* * *}$ \\
Observations & $(0.0348)$ & $(0.0427)$ & $(1.686)$ & $(0.750)$ \\
$R^{2}$ & 281 & 227 & 281 & 115 \\
\hline
\end{tabular}

Robust Standard errors in parentheses

${ }^{*} p<0.10,{ }^{* *} p<0.05,{ }^{* * *} p<0.01$

Notes: ${ }^{a}$ Disadvantaged section includes total share of SC/ST/OBC in total population

${ }^{\mathrm{b}}$ Excludes Rajasthan \& Madhya Pradesh

c Consists of the predominantly princely states, i.e. Rajasthan, Tripura, Kerala, Gujarat, Madhya Pradesh, Orissa and parts of Karnataka (Mysore). 
Table 6: Channels of Impact for Elections of 1977

\begin{tabular}{|c|c|c|c|c|c|c|}
\hline \multirow[t]{2}{*}{1977} & \multicolumn{2}{|c|}{ Voter Turnout } & \multicolumn{2}{|c|}{ Margin of Victory } & \multicolumn{2}{|c|}{ Electoral Competition } \\
\hline & Full Sample & Sub Sample b & Full Sample & Sub Sample c & Full Sample & Sub Sampled \\
\hline \multirow[t]{2}{*}{ Colonial } & $-0.0448^{* * *}$ & -0.0231 & $0.144^{* * *}$ & 0.0109 & $5.786^{* * *}$ & 1.607 \\
\hline & $(0.0156)$ & $(0.0194)$ & $(0.0448)$ & $(0.0464)$ & $(1.035)$ & $(1.066)$ \\
\hline \multirow[t]{2}{*}{ Col-Non landlord } & 0.0199 & -0.00379 & $-0.0647^{*}$ & -0.00261 & $-4.679^{* * *}$ & -1.215 \\
\hline & $(0.0136)$ & $(0.0171)$ & $(0.0388)$ & $(0.0425)$ & $(1.059)$ & $(1.133)$ \\
\hline \multirow[t]{2}{*}{ Percentage Literate } & $0.147^{*}$ & $0.379^{* * *}$ & -0.132 & $-0.651^{* * *}$ & -0.536 & -0.234 \\
\hline & $(0.0889)$ & $(0.0560)$ & $(0.183)$ & $(0.142)$ & $(1.800)$ & $(2.904)$ \\
\hline Total Population & 7.860 & $9.888^{* *}$ & -3.205 & 1.502 & 418.1 & -23.03 \\
\hline (in Billions) & $(5.210)$ & $(4.320)$ & $(4.689)$ & $(31.64)$ & $(560.3)$ & $(138.8)$ \\
\hline Urban Population & -10.34 & $-36.95^{* * *}$ & -11.59 & -32.94 & $6530.0^{* * *}$ & $7454.7^{* * *}$ \\
\hline (in Billions) & $(13.44)$ & $(8.929)$ & $(24.00)$ & $(45.73)$ & $(868.3)$ & $(723.5)$ \\
\hline Fragmentation & $0.121^{* * *}$ & 0.0665 & -0.0933 & 0.153 & 0.294 & 0.374 \\
\hline Index & $(0.0420)$ & $(0.0518)$ & $(0.0823)$ & $(0.125)$ & $(2.484)$ & $(2.201)$ \\
\hline Disadvantaged & $-0.236^{* * *}$ & $-0.258^{* * *}$ & 0.159 & $-0.137^{*}$ & -1.918 & -1.755 \\
\hline Section ${ }^{a}$ & $(0.0492)$ & $(0.0541)$ & $(0.180)$ & $(0.0802)$ & $(1.780)$ & (1.618) \\
\hline \multirow[t]{2}{*}{ Constant } & $0.589^{* * *}$ & $0.544^{* * *}$ & $0.241^{* * *}$ & $0.405^{* * *}$ & $3.676^{* * *}$ & $4.067^{* * *}$ \\
\hline & $(0.0318)$ & $(0.0301)$ & $(0.0687)$ & $(0.0539)$ & (1.120) & (1.121) \\
\hline Observations & 282 & 183 & 282 & 113 & 282 & 138 \\
\hline$R^{2}$ & 0.307 & 0.344 & 0.104 & 0.217 & 0.543 & 0.708 \\
\hline
\end{tabular}

Robust Standard errors in parentheses

${ }^{*} p<0.10,{ }^{* *} p<0.05,{ }^{* * *} p<0.01$

Notes: ${ }^{a}$ Disadvantaged section includes total share of SC/ST/OBC in total population

b Subsample excludes the states of Rajasthan, Madhya Pradesh and Uttar Pradesh.

c Subsample consists of the states of Rajasthan, Madhya Pradesh, Tripura, Kerala, Gujarat, Orissa and parts of Karnataka (Mysore).

d Subsample excludes the states of West Bengal, Bihar, Rajasthan, Madhya Pradesh, Tamil Nadu and Uttar Pradesh. 
Even as administrative institutions that existed pre-Independence were dismantled post-Independence, such institutions seem to shape societal responses to state action in ways that in turn impact electoral outcomes. This research unearths empirically such evidence; I find that even after decolonization, princely states have a four percent higher voter turnout in comparison to the erstwhile colonial territories in the elections of 1951. In the same elections, the colonial areas, on an average, have three more persons contesting elections for each seat than in the princely states. Such effects do not dissipate in the long run. Similarly, even though land reforms were enacted to abolish the system of tenancy instituted by the British, tenancy was still likely influencing voter turnouts in the elections of 1951 and the non-landlord areas, on an average had five percent higher voter turnout than the landlord areas. In the longer term, one would expect that the colonial legacies would dissipate, but I find that even after the institutions cease to exist formally, they are still influential. In the elections of 1971 and 1977, the princely states, on an average, have four percent higher voter turnout in comparison to the erstwhile colonial ruled areas. Similarly, electoral competition in the elections of 1971 and 1977 indicate that the colonial areas had an average of five and six candidates more (respectively), than princely states. The elections of 1977, held after the watershed event of the National Emergency of 1975, which changed the socio-political landscape of the country, still indicates the impacts of these legally non-existent institutions on the electoral outcomes.

These results highlight two issues. If historical institutions influence resource allocation, policy and economic outcomes, understanding the mediating role of political and electoral process is key. At this time, those studying elections appear to limit the role of 
history if not neglecting it altogether and those studying history of institutions do not often study the role of electoral outcomes. This paper provides a case for both. A second contribution is to emphasize that 'institutional overhang' need not be static and does not necessarily persist in its original form. In the Indian case, not only was substantial effort made by the state to negate the differences across native and British provinces via an inclusive preparation of a voter list, there was also a systematic attempt to reform tenancy laws to empower the tenants in areas where the land tenure engendered class differences. Even though the colonial institutions have been long dismantled they still influence electoral outcomes. This work brings forth the path dependent nature of political institutions and modulation of responses to state interventions seeking to reduce the existing differences. Thus, formal attempts to dismantle the historical institutions have not rendered them irrelevant.

This paper emphasizes that historical perspectives help uncover the channel through which the present day institutions/ conventions became 'carriers of history'. The path-dependent nature of contemporary institutions provides a rationale for studying institutions in continuity/sequence, rather than in chunks of time (David 1994). This can not only lead to enriching policy options, but neglecting them may lead to erroneous interpretations (Woolcock, Rao, and Szreter 2010). The findings in this paper, serve to encourage development practitioners, as other research has done before, to pay heed to the 'impact trajectory' of today's policy in the future, as it becomes moulded by both past and present contexts. 


\section{REFERENCES}

Acemoglu, Daron, Simon Johnson, and James A. Robinson. 2001. "The Colonial Origins of Comparative Development: An Empirical Investigation." American Economic Review 91 (5): 1369-1401.

Agbor, Julius A. 2015. "13 How Does Colonial Origin Matter for Economic Performance in Sub-Saharan Africa?" Growth and Institutions in African Development 117: 309.

Alam, Mohd Sanjeer. 2010. “On Matching Census Tracts and Electoral Boundaries: The Bottom-up Aggregation Approach." Economic and Political Weekly, 64-72.

Baden-Powell, Baden Henry. 1892. The Land-Systems of British India. Vol. 2. Clarendon Press.

Banerjee, Abhijit, and Lakshmi Iyer. 2005. "History, Institutions, and Economic Performance: The Legacy of Colonial Land Tenure Systems in India." American Economic Review 95 (4): 1190-1213.

Banerjee, Abhijit, Lakshmi Iyer, and Rohini Somanathan. 2005. "History, Social Divisions, and Public Goods in Rural India." Journal of the European Economic Association 3 (2-3): 639-647. 
Banerjee, Abhijit, and Rohini Somanathan. 2001. "Caste, Community and Collective Action: The Political Economy of Public Good Provision in India." mimeo, Massachusetts Institute of Technology.

——_. 2007. "The Political Economy of Public Goods: Some Evidence from India." Journal of Development Economics 82 (2): 287-314.

Banerjee, Abhijit V., and Lakshmi Iyer. 2008. Colonial Land Tenure, Electoral Competition and Public Goods in India. Harvard Business School.

Banerjee, Mukulika. 2007. "Sacred Elections." Economic and Political Weekly, 15561562.

———. 2011. "Elections as Communitas." Social Research 78 (1): 75-98.

Baxi, Upendra. 1990. “The Recovery of Fire: Nehru and Legitimation of Power in India." Economic and Political Weekly, 107-112.

Becker, Sascha O., Katrin Boeckh, Christa Hainz, and Ludger Woessmann. 2016. “The Empire Is Dead, Long Live the Empire! Long-Run Persistence of Trust and Corruption in the Bureaucracy." The Economic Journal 126 (590): 40-74.

Beg, Sabrin. 2016. “Traditional Elites: Agricultural Productivity and the Persistence of Political Power." Working paper. 
Bertocchi, Graziella, and Fabio Canova. 2002. “Did Colonization Matter for Growth?: An Empirical Exploration into the Historical Causes of Africa's Underdevelopment." European Economic Review 46 (10): 1851-1871.

Besley, Timothy, and Robin Burgess. 2000. "Land Reform, Poverty Reduction, and Growth: Evidence from India." The Quarterly Journal of Economics 115 (2): 389-430.

Bowles, Samuel, Jung-Kyoo Choi, and Astrid Hopfensitz. 2003. "The Co-Evolution of Individual Behaviors and Social Institutions." Journal of Theoretical Biology 223 (2): 135147.

Brass, Paul R. 1994. The Politics of India since Independence. Vol. 1. Cambridge University Press.

Copland, Ian. 2002. The Princes of India in the Endgame of Empire, 1917-1947. Vol. 2. Cambridge University Press.

David, Paul A. 1994. "Why Are Institutions the 'Carriers of History'?: Path Dependence and the Evolution of Conventions, Organizations and Institutions." Structural Change and Economic Dynamics 5 (2): 205-220.

Dollar, David, and Aart Kraay. 2003. "Institutions, Trade, and Growth." Journal of Monetary Economics 50 (1): 133-162.

Ekeh, Peter Palmer. 1983. Colonialism and Social Structure: An Inaugural Lecture Delivered at the University of Ibadan on Thursday, 5 June 1980. University of Ibadan. 
Ghatak, Maitreesh, and Sanchari Roy. 2007. "Land Reform and Agricultural Productivity in India: A Review of the Evidence." Oxford Review of Economic Policy 23 (2): 251-269.

Gohit, Rajiv Kumar. 2007. Social and Economic History of Modern India. Murari Lal.

Gordon, Neve. 2010. “Democracy and Colonialism.” Theory \& Event 13 (2).

Gough, Kathleen. 1974. "Indian Peasant Uprisings.” Economic and Political Weekly, $1391-1412$.

Hayami, Yujiro, and Vernon W. Ruttan. 1970. "Korean Rice, Taiwan Rice, and Japanese Agricultural Stagnation: An Economic Consequence of Colonialism." The Quarterly Journal of Economics, 562-589.

Helmke, Gretchen, and Steven Levitsky. 2004. "Informal Institutions and Comparative Politics: A Research Agenda." Perspectives on Politics 2 (4): 725-740.

Hodgson, Geoffrey M. 1988. "Economics and Institutions." In Journal of Economic Issues. Citeseer.

Hsiao, Cheng, and Yan Shen. 2003. "Foreign Direct Investment and Economic Growth: The Importance of Institutions and Urbanization." Economic Development and Cultural Change 51 (4): 883-896.

Iversen, Vegard, Richard Palmer-Jones, and Kunal Sen. 2013. "On the Colonial Origins of Agricultural Development in India: A Re-Examination of Banerjee and 
Iyer,'History, Institutions and Economic Performance.'” Journal of Development Studies 49 (12): 1631-1646.

Iyer, Lakshmi. 2004. The Long-Term Impact of Colonial Rule: Evidence from India. Citeseer.

Jaffrelot, Christophe. 1999. The Hindu Nationalist Movement and Indian Politics: 1925 to the 1990s: Strategies of Identity-Building, Implantation and Mobilisation (with Special Reference to Central India). Penguin Books India.

Joshi, Madhav, and T. David Mason. 2007. “Land Tenure, Democracy, and Insurgency in Nepal: Peasant Support for Insurgency versus Democracy." Asian Survey 47 (3): 393414.

Kapur, Shilpi, and Sukkoo Kim. 2006. "British Colonial Institutions and Economic Development in India." National Bureau of Economic Research.

Klerman, Daniel M., Paul G. Mahoney, Holger Spamann, and Mark I. Weinstein. 2011. “Legal Origin or Colonial History?” Journal of Legal Analysis 3 (2): 379-409.

Knight, Jack. 1992. Institutions and Social Conflict. Cambridge University Press.

Lankina, Tomila V. 2014. “'Trends in Within-Legacy and Cross-Legacy Analysis of Democracy and Development.' In Colonialism and Democratization, Eds. Matthew D. Fails and Jonathan Krieckhaus." The American Political Science Association Comparative Democratization Newsletter 12 (1): 7-11. 
Mies, Maria. 1976. “The Shahada Movement: A Peasant Movement in Maharashtra (India) - Its Development and Its Perspectives." The Journal of Peasant Studies 3 (4): 472482.

Mori, Yuko, and Takashi Kurosaki. 2013. "Does Political Reservation Affect Voting Behavior? Empirical Evidence from India."

Mukherji, Partha. 1987. "Study of Social Conflicts: Case of Naxalbari Peasant Movement." Economic and Political Weekly, 1607-1617.

North, Douglass C. 1991. “Institutions.” Journal of Economic Perspectives 5 (1): 97112.

Olsson, Ola. 2009. "On the Democratic Legacy of Colonialism." Journal of Comparative Economics 37 (4): 534-551.

Persson, Torsten, and Guido Tabellini. 2004. "Constitutional Rules and Fiscal Policy Outcomes." American Economic Review 94 (1): 25-45.

Qanungo, Bhupen. 1967. "A Study of British Relations with the Native States of India, 1858-62." The Journal of Asian Studies 26 (2): 251-265.

Richter, William L. 1971. "Princes in Indian Politics." Economic and Political Weekly, $535-542$. 
Richter, William L., and Barbara Ramusack. 1975. "The Chamber and the Consultation: Changing Forms of Princely Association in India." The Journal of Asian Studies 34 (3): 755-776.

Roy, Tirthankar. 2014. “Geography or Politics? Regional Inequality in Colonial India." European Review of Economic History 18 (3): 324-348.

Rudolph, Lloyd I., and Susanne Hoeber Rudolph. 1966. "Rajputana under British Paramountcy: The Failure of Indirect Rule." The Journal of Modern History 38 (2): 138160.

Rudolph, Susanne Hoeber. 1963. “The Princely States of Rajputana: Ethic, Authority and Structure." The Indian Journal of Political Science 24 (1): 14-32.

Sarkar, Sumit. 1997. Writing Social History. Oxford University Press New Delhi.

Shani, Ornit. 2017. How India Became Democratic: Citizenship and the Making of the Universal Franchise. Cambridge University Press.

Tenn, Steven. 2007. “The Effect of Education on Voter Turnout.” Political Analysis 15 (4): 446-464.

Vanhanen, Tatu. 2000. “A New Dataset for Measuring Democracy, 1810-1998." Journal of Peace Research 37 (2): 251-265.

———. 2005. "Measures of Democracy 1810-2004." Computer File]. FSD1289, Version 2. 
Wiener, Martin J. 2013. “The Idea of 'Colonial Legacy' and the Historiography of Empire." Journal of the Historical Society 13 (1): 1-32.

Woolcock, Michael, Vijayendra Rao, and Simon Szreter. 2010. How and Why Does History Matter for Development Policy? The World Bank. 


\section{APPENDIX}

Table A 1: Descriptive Statistics Based on type of Rule

\begin{tabular}{|c|c|c|c|c|c|c|c|c|c|c|c|c|}
\hline \multirow{3}{*}{ Variables } & \multicolumn{4}{|c|}{1951} & \multicolumn{4}{|c|}{1971} & \multicolumn{4}{|c|}{1977} \\
\hline & \multicolumn{2}{|c|}{ Native } & \multicolumn{2}{|c|}{ Colonial } & \multicolumn{2}{|c|}{ Native } & \multicolumn{2}{|c|}{ Colonial } & \multicolumn{2}{|c|}{ Native } & \multicolumn{2}{|c|}{ Colonial } \\
\hline & Mean & $\mathrm{SD}$ & Mean & SD & Mean & SD & Mean & SD & Mean & SD & Mean & SD \\
\hline Percentage Literate & 12.39 & 10.42 & 15.84 & 8.14 & 27.30 & 13.32 & 30.14 & 18.03 & 27.07 & 13.30 & 30.01 & 18.02 \\
\hline $\begin{array}{l}\text { Total Population } \\
\text { (in Millions) }\end{array}$ & 0.83 & 0.49 & 1.47 & 0.78 & 1.30 & 0.56 & 2.26 & 2.08 & 1.29 & 0.56 & 2.26 & 2.08 \\
\hline $\begin{array}{l}\text { Urban Population } \\
\text { (in Millions) }\end{array}$ & 0.13 & 0.16 & 0.24 & 0.32 & 0.24 & 0.27 & 0.45 & 0.68 & 0.24 & 0.27 & 0.45 & 0.68 \\
\hline $\begin{array}{l}\text { Fragmentation } \\
\text { Index }\end{array}$ & 0.19 & 0.14 & 0.23 & 0.14 & 0.23 & 0.15 & 0.26 & 0.14 & 0.23 & 0.15 & 0.26 & 0.14 \\
\hline Share of SC & 0.13 & 0.07 & 0.15 & 0.07 & 0.14 & 0.07 & 0.15 & 0.08 & 0.14 & 0.07 & 0.15 & 0.08 \\
\hline Share of OBC & 0.02 & 0.06 & 0.03 & 0.08 & - & - & - & - & - & - & - & - \\
\hline Share ST & 0.08 & 0.17 & 0.06 & 0.15 & 0.12 & 0.19 & 0.06 & 0.13 & 0.12 & 0.19 & 0.07 & 0.13 \\
\hline $\begin{array}{l}\text { Voter turnout } \\
\text { Shares }\end{array}$ & 0.43 & 0.14 & 0.47 & 0.12 & 0.55 & 0.10 & 0.54 & 0.12 & 0.60 & 0.13 & 0.59 & 0.10 \\
\hline Margin of Victory & 0.18 & 0.14 & 0.17 & 0.12 & 0.23 & 0.17 & 0.27 & 0.16 & 0.22 & 0.15 & 0.31 & 0.24 \\
\hline $\begin{array}{l}\text { Electoral } \\
\text { Competition }\end{array}$ & 5.34 & 3.10 & 9.76 & 5.15 & 6.17 & 3.72 & 11.33 & 8.55 & 5.34 & 3.27 & 9.94 & 7.66 \\
\hline$N$ & & & & & & & & & & 2 & & \\
\hline
\end{tabular}


Table A 2: Descriptive Statistics Based on Type of Land Tenure

\begin{tabular}{|c|c|c|c|c|c|c|c|c|c|c|c|c|}
\hline \multirow{3}{*}{ Variables } & \multicolumn{4}{|c|}{1951} & \multicolumn{4}{|c|}{1971} & \multicolumn{4}{|c|}{1977} \\
\hline & \multicolumn{2}{|c|}{ Landlord } & \multicolumn{2}{|c|}{ Non-landlord } & \multicolumn{2}{|c|}{ Landlord } & \multicolumn{2}{|c|}{ Non-landlord } & \multicolumn{2}{|c|}{ Landlord } & \multicolumn{2}{|c|}{ Non-landlord } \\
\hline & Mean & SD & Mean & SD & Mean & SD & Mean & SD & Mean & SD & Mean & SD \\
\hline Percentage Literate & 11 & 7.64 & 16.80 & 8.32 & 25.10 & 10.74 & 33.17 & 20.71 & 25.10 & 10.74 & 32.96 & 20.71 \\
\hline $\begin{array}{l}\text { Total Population } \\
\text { (in Millions) }\end{array}$ & 1.84 & 0.87 & 1.26 & 0.62 & 3.01 & 3.04 & 1.81 & 0.97 & 3.01 & 3.04 & 1.81 & 0.96 \\
\hline $\begin{array}{l}\text { Urban Population } \\
\text { (in Millions) }\end{array}$ & 0.27 & 0.38 & 0.23 & 0.27 & 0.45 & 0.56 & 0.46 & 0.74 & 0.45 & 0.56 & 0.45 & 0.74 \\
\hline Fragmentation & 0.24 & 0.13 & 0.22 & 0.14 & 0.27 & 0.16 & 0.25 & 0.13 & 0.27 & 0.16 & 0.24 & 0.13 \\
\hline Index & & & & & & & & & & & & \\
\hline Share of SC & 0.16 & 0.08 & 0.14 & 0.06 & 0.17 & 0.08 & 0.14 & 0.08 & 0.17 & 0.08 & 0.14 & 0.08 \\
\hline Share of OBC & 0.04 & 0.09 & 0.02 & 0.08 & - & - & - & - & - & - & - & - \\
\hline Share ST & 0.08 & 0.17 & 0.05 & 0.14 & 0.07 & 0.13 & 0.06 & 0.13 & 0.07 & 0.13 & 0.06 & 0.13 \\
\hline $\begin{array}{l}\text { Voter turnout } \\
\text { Shares }\end{array}$ & 0.44 & 0.13 & 0.49 & 0.11 & 0.53 & 0.13 & 0.54 & 0.11 & 0.57 & 0.12 & 0.60 & 0.08 \\
\hline Margin of Victory & 0.12 & 0.09 & 0.19 & 0.13 & 0.24 & 0.15 & 0.29 & 0.16 & 0.35 & 0.32 & 0.28 & 0.16 \\
\hline $\begin{array}{l}\text { Electoral } \\
\text { Competition }\end{array}$ & 12.14 & 5.17 & 8.32 & 4.59 & 13.79 & 8.43 & 9.82 & 8.31 & 12.87 & 7.68 & 8.13 & 7.09 \\
\hline$N$ & & & & & & & & & & & & \\
\hline
\end{tabular}


